\title{
Psychological contract breach and voluntary turnover among newcomers: the role of supervisor trustworthiness and negative affectivity
}

\author{
Émilie Lapointe ${ }^{1}$ (D) and Christian Vandenberghe ${ }^{2}$ (D) \\ ${ }^{1}$ BI Norwegian Business School, Nydalsveien 37, 0484, Oslo, Norway and ${ }^{2}$ HEC Montréal, 3000 Chemin de la Côte Sainte- \\ Catherine, Montréal, Québec H3T 2A7, Canada \\ Author for correspondence: Émilie Lapointe, E-mail: Emilie.Lapointe@bi.no
}

(Received 3 July 2020; revised 30 November 2020; accepted 2 December 2020)

\begin{abstract}
This article looks at the relationship between psychological contract breach and voluntary turnover among newcomers, using supervisor trustworthiness as a mediator and negative affectivity as a moderator. Relying on data from 243 newcomers, psychological contract breach was found to be negatively related to the three dimensions of supervisor trustworthiness, i.e., ability, benevolence, and integrity. Supervisor integrity further mediated a positive relationship between psychological contract breach and voluntary turnover measured 8 months later. Psychological contract breach interacted with negative affectivity such that it was less negatively related to dimensions of supervisor trustworthiness at high levels of negative affectivity. The indirect relationship of psychological contract breach to voluntary turnover as mediated by supervisor integrity was also weaker at high levels of negative affectivity. We discuss the implications of these findings for research and practice.
\end{abstract}

Key words: Negative affectivity; newcomers; psychological contract breach; supervisor trustworthiness; voluntary turnover

\section{Introduction}

During the organizational socialization period, newcomers experience a major adjustment of their cognitive schemes and develop an understanding of the mutual obligations that link them to the organization (De Vos, Buyens, \& Schalk, 2003; Payne, Culbertson, Lopez, Boswell, \& Barger, 2015; Tekleab, Orvis, \& Taylor, 2013; see also Saks \& Ashforth, 1997). In this context, a perception of psychological contract breach whereby the organization is seen to have failed to fulfill its obligations toward newcomers is likely to have deleterious consequences (Morrison \& Robinson, 1997; Zhao, Wayne, Glibkowski, \& Bravo, 2007). Previous work suggested that breaches to the psychological contract occurring in the first few months after organizational entry may impede newcomer adjustment (Woodrow \& Guest, 2020). Theoretical explanations for the negative effects of psychological contract breach have focused on the key mediating role of employees' affective reactions (Cassar \& Briner, 2011; Morrison \& Robinson, 1997; Zhao et al., 2007). More precisely, the perception of a breach to the psychological contract would trigger a negative emotional experience (e.g., anger, frustration or, more broadly, feelings of violation or mistrust) which would influence how newcomers think and act in the workplace. Although focusing on employees' affective reactions as mediators is worthwhile, as shown in a recent meta-analysis (Zhao et al., 2007), we argue that it does not fully capture newcomers' experience of psychological contract breach and that other approaches are worth considering.

(c) Cambridge University Press and Australian and New Zealand Academy of Management 2021. This is an Open Access article, distributed under the terms of the Creative Commons Attribution licence (http://creativecommons.org/licenses/by/4.0/), which permits unrestricted reuse, distribution, and reproduction in any medium, provided the original work is properly cited. 
Indeed, by directly focusing on employees' affective reactions as a mediating mechanism, researchers might overlook significant, overarching cognitive processes that could explain the relationship between psychological contract breach and work outcomes. In this regard, attributional processes (Heider, 1958; Martinko, Harvey, \& Dasborough, 2011) appear particularly interesting. Indeed, individuals naturally make attributions regarding the causes of what they experience, and these attributions are known to have a substantial influence over their attitudes and behaviors (Martinko, Harvey, \& Dasborough, 2011). As Heider (1958) mentioned in his classical work, individuals tend to behave as naïve psychologists and seek to explain what they experience to better understand and adjust to their environment. Previous theoretical work on psychological contracts (Morrison \& Robinson, 1997; Rousseau, 1995; Turnley \& Feldman, 1999) suggests, in this regard, that employees try to make sense of the reasons why psychological contract breach has occurred. For example, Morrison and Robinson (1997; see also Lester, Turnley, Bloodgood, \& Bolino, 2002) suggested that different attributions possibly lead to different outcomes, with employees reacting more negatively to intentional contract breach. Building on this work, Ng, Feldman, and Butts (2014) suggested that supervisors may be seen, to some extent, as responsible for contract breach. However, this possibility has yet to be empirically examined.

The present study aims to fill this gap. We seek to contribute to the literature on psychological contracts by testing the premises of an attributional perspective of psychological contract breach. We argue that newcomers cognitively attribute psychological contract breach to a lack of trustworthiness of their supervisor (Mayer, Davis, \& Schoorman, 1995), which is defined as the attributes or characteristics of the supervisor, including ability, benevolence, and integrity, that inspire trust (Colquitt, Scott, \& LePine, 2007). Indeed, supervisors are likely to be central targets of newcomers' attributions given their role as salient socialization agents (Nifadkar, 2020; Saks \& Ashforth, 1997; Zou, Tian, \& Liu, 2015) and given that, as proximal representatives of the organization, they are gatekeepers of the organization's promises (Dabos \& Rousseau, 2004; Solberg, Lapointe, \& Dysvik, 2020; Welander, Blomberg, \& Isaksson, 2020; Woodrow \& Guest, 2020). Supervisors are also directly accountable for some aspects of the realization of the psychological contract, including the arrangement of promised obligations on behalf of the organization (Coyle-Shapiro \& Shore, 2007; Dabos \& Rousseau, 2004; Lester et al., 2002; Solberg, Lapointe, \& Dysvik, 2020; Welander, Blomberg, \& Isaksson, 2020; Woodrow \& Guest, 2020). Thus, the extent to which they are perceived to fulfill their roles in a trustful manner might explain the breach's effect on newcomer voluntary turnover. Specifically, we contend that the benevolence (i.e., a willingness to 'do good' to the employee) and integrity (i.e., adherence to acceptable principles and values) dimensions of trustworthiness, but not the ability (i.e., competence and skills) dimension (Colquitt, Scott, \& LePine, 2007; Mayer, Davis, \& Schoorman, 1995), will play a mediating role between contract breach and outcomes due to them implying a responsibility of the supervisor for contract breach (Morrison \& Robinson, 1997). We specifically focus on voluntary turnover as the key outcome because the intermediate paths between contract breach and voluntary turnover are debated in the recent literature (Clinton \& Guest, 2014; Zhao et al., 2007) and supervisor trustworthiness remains a neglected mechanism in this process that bears implications for employees' future in the organization (Dirks \& Ferrin, 2002).

Moreover, in light of recent psychological contract research emphasizing the key role of individual dispositions (e.g., Gardner, Huang, Niu, Pierce, \& Lee, 2015; Shih \& Chuang, 2013; see also Rousseau, Hansen, \& Tomprou, 2018), we argue that the aforementioned attributional process is moderated by newcomers' level of negative affectivity (Watson, Clark, \& Tellegen, 1988). Indeed, as newcomers do not have developed yet a clear frame of reference to understand their environment, their experiences are likely to be affected by their dispositions (Eberl, Ute, \& Möller, 2012; Saks \& Ashforth, 1997). This is because dispositions may play a more salient role in explaining how individuals make sense of situations and respond to them in times of uncertainty (Saks \& Ashforth, 1997). We specifically focus on negative affectivity (Watson, Clark, \& Tellegen, 
1988), which has been largely overlooked in organizational socialization research (for a recent exception, see Vandenberghe, Panaccio, Bentein, Mignonac, Roussel, \& Ben Ayed, 2019). Yet, research in other domains (e.g., pay satisfaction; Begley \& Lee, 2005) has demonstrated that negative affectivity involves a pessimistic view of the world. Employees with high levels of negative affectivity tend to expect negative fallouts and get prepared for negative situations (Judge \& Larsen, 2001). Consequently, when they experience something negative, they are less surprised and react less negatively (Begley \& Lee, 2005; Judge \& Larsen, 2001). We argue that the specific way of thinking and behaving that is associated with negative affectivity is important in connection with psychological contract breach. Thus, we aim to contribute to the literature by examining its role. More specifically, we contend, in line with the met expectations hypothesis (Begley \& Lee, 2005), that newcomers with high negative affectivity will be less likely to question their supervisor's trustworthiness after having experienced contract breach and will ultimately be less likely to leave as a result. In other words, we hypothesize that the impact of breach on supervisor trustworthiness and, indirectly, on voluntary turnover will be reduced among newcomers with high negative affectivity.

Adopting an alternative, attributional perspective to examine psychological contract breach's effects is a worthwhile research endeavor as contract breach is experienced by a high proportion of employees and its effects can be long-lasting and difficult to repair (Conway \& Briner, 2002; Conway, Guest, \& Trenberth, 2011; Robinson \& Rousseau, 1994). It is also particularly important among newcomers, who, following organizational entry, actively seek to understand the terms of the psychological contract and assess whether and why it has been breached (De Vos, Buyens, \& Schalk, 2003; Morrison \& Robinson, 1997; Payne et al., 2015; see also Rousseau, Hansen, \& Tomprou, 2018). Organizations may also benefit from ensuring that they begin their relationship with employees on a positive note (Woodrow \& Guest, 2020). Considering that trustworthiness dimensions are distinguishable from, and more specific than, trust, and incrementally predict work outcomes over and above trust (Colquitt \& Rodell, 2011; Colquitt, Scott, \& LePine, 2007; Legood, Thomas, \& Sacramento, 2016), this study is also timely and relevant as it will help determine which facets of trustworthiness are critical to newcomers' experience. Finally, examining the moderating role of negative affectivity is worthwhile as it will help to test the viability of the met expectations hypothesis (Begley \& Lee, 2005) in the context of attitudinal and behavioral reactions to contract breach, which, to our knowledge, has not been done to date. Doing so contributes to expand research on the role of trait affectivity during organizational socialization (Vandenberghe et al., 2019). It also contributes to answer calls (Rousseau, Hansen, \& Tomprou, 2018) to improve understanding of the role played by individual dispositions in the psychological contract breach process. Our research model is depicted in Figure 1.

\section{Theoretical background and hypothesis development}

\section{Psychological contract and psychological contract breach}

The psychological contract is an implicit agreement between employees and their organization (Robinson, 1996; Rousseau, 1995, 2001). More specifically, the psychological contract captures employees' beliefs about the organization's obligations toward them as well as their beliefs about their own obligations toward the organization (Morrison \& Robinson, 1997; Robinson \& Morrison, 2000; Rousseau, Hansen, \& Tomprou, 2018). These beliefs may concern salary and benefits or training and development opportunities, among other possibilities, and often reflect promises that employees perceive were being made to them (Herriot, Manning, \& Kidd, 1997; Rousseau, Hansen, \& Tomprou, 2018; Solberg, Lapointe, \& Dysvik, 2020). When employees perceive that the organization has failed to fulfil its obligations toward them, the psychological contract is said to be breached (Morrison \& Robinson, 1997). Thus, psychological contract breach is a subjective experience (Morrison \& Robinson, 1997; Robinson, 1996). It reflects employees' 


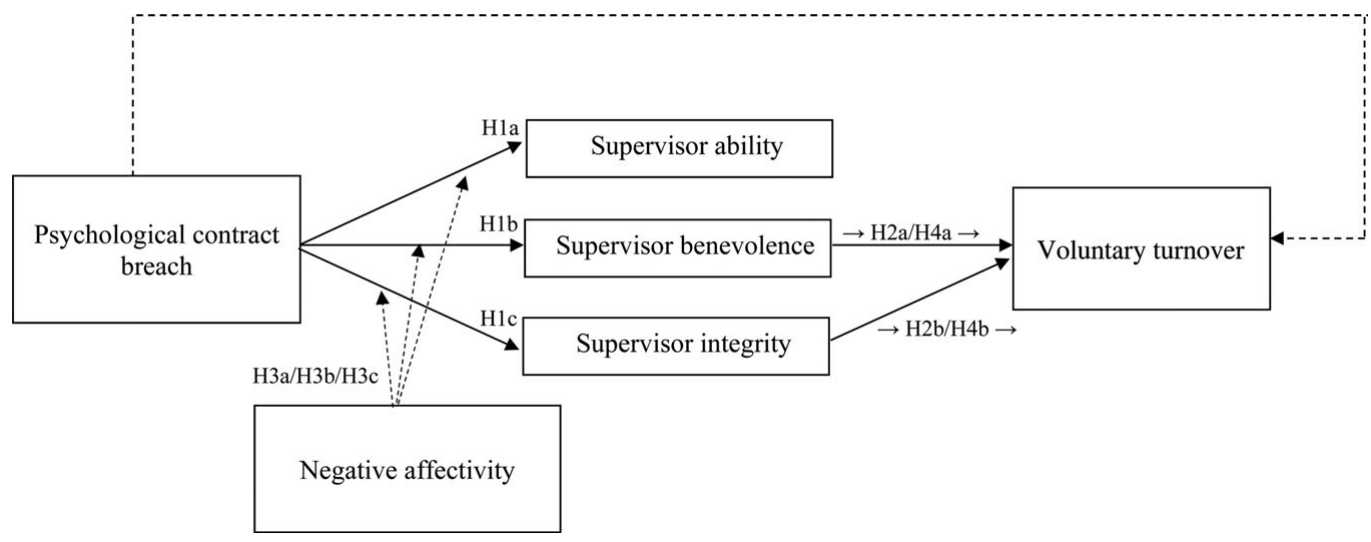

Figure 1. Research model and hypotheses for the study.

perception of what the organization delivered versus did not deliver but not necessarily what the organization actually delivered or not (Robinson, 1996). Psychological contract breach can hinder newcomers' adjustment to the organization and, as suggested by Woodrow and Guest (2020: 114), has 'the potential to damage the developing employment relationship, leading to negative attitudes and behaviour, poorer social relationships, inhibited learning, and, potentially, turnover.'

\section{Psychological contract breach and supervisor trustworthiness}

Rooted in social psychology, attribution theories explore how individuals make attributions about the causes of what they experience and how this process affects their attitudes and behaviors (Kelley, 1973; Kelley \& Michela, 1980; Martinko, Harvey, \& Dasborough, 2011; Weiner, 1986; see also Tomlinson \& Mayer, 2009). Of importance, research suggests that the nature of the attributions individuals make is critical to determine their responses (Kelley, 1973; Zapata, Olsen, \& Martins, 2013; see also Little, Roberts, Jones, \& DeBruine, 2012; Rule, Krendl, Ivcevic, \& Ambady, 2013). Attributional theories have been used in recent research to explain how individuals respond to actions by organizations (Munyon, Jenkins, Crook, Edwards, \& Harvey, 2019), supervisors (e.g., Lapointe, Vandenberghe, Ben Ayed, Schwarz, Tremblay, \& Chenevert, 2020; Matta, Sabey, Scott, Lin, \& Koopman, 2020), and coworkers (Puranik, Koopman, Vough, \& Gamache, 2019), among other referents. Building on these recent research developments, we suggest that, in the organizational context, newcomers seek to attribute the plausible causes of contract breach to supervisor behaviors demonstrating a lack of trustworthiness.

Trustworthiness (which should not be confounded with trust itself; Colquitt, Scott, \& LePine, 2007) refers to the personal characteristics of a party that foster trust from another party (Mayer, Davis, \& Schoorman, 1995). Following Mayer, Davis, and Schoorman (1995), these separate yet related characteristics are ability, benevolence, and integrity. Ability is that group of skills, competencies, and characteristics that enable a trustee to have influence within some specific domain. It captures the 'can-do' dimension of trustworthiness (Colquitt, Scott, \& LePine, 2007). Benevolence is the extent to which a trustee is believed to wish the good of the trustor, excluding egocentric motives. Integrity is defined as the perception that the trustee adheres to a set of principles that the trustor finds acceptable and acts in accordance with these principles. By describing whether the trustee will be willing to use his or her abilities to act in ways that favor the trustor, benevolence and integrity capture the 'will-do' aspects of trustworthiness (Colquitt, Scott, \& LePine, 2007). Thus, our reasoning is that supervisor behaviors may be viewed as indicating a lack of ability, benevolence, and integrity, when employees experience psychological contract breach. 
First, psychological contract breach could be attributed to a lack of ability of the supervisor. For example, failing to help a deserving newcomer benefit from organizational policies (e.g., training and development) or failing to master important aspects of one's supervisory role refers to lack of supervisor ability (Searle \& Dietz, 2012; Treadway et al., 2004). Psychological contract breach could also be attributed to a lack of benevolence of the supervisor. A negative or cynical orientation of the supervisor toward newcomers, whereby the best interests of newcomers are left behind, could, for instance, be an explanation for contract breach (Colquitt, Scott, \& LePine, 2007; Mayer, Davis, \& Schoorman, 1995). Finally, psychological contract breach could be attributed to a lack of integrity of the supervisor. This would happen when supervisors fail to follow up on particular promises they made in the name of the organization because they do not endorse them anymore or because these promises do not match their own interests (Coyle-Shapiro \& Shore, 2007; Morrison \& Robinson, 1997). Thus, the three dimensions of trustworthiness are likely to be affected by breach. Our reasoning is supported by previous research suggesting that employees' perception of being treated unfairly (which is closely related to contract breach perceptions; Rosen, Chang, Johnson, \& Levy, 2009) influences the extent to which the supervisor is viewed as being trustworthy (Colquitt \& Rodell, 2011; Frazier, Johnson, Gavin, Gooty, \& Snow, 2010). Therefore, we propose the following hypotheses.

Hypothesis 1a: Psychological contract breach will be negatively related to perceived supervisor ability.

Hypothesis 1b: Psychological contract breach will be negatively related to perceived supervisor benevolence.

Hypothesis 1c: Psychological contract breach will be negatively related to perceived supervisor integrity.

\section{Relationship between contract breach and voluntary turnover: supervisor benevolence and integrity as mediators}

As suggested in previous research (e.g., Colquitt, Scott, \& LePine, 2007; see also Legood, Thomas, \& Sacramento, 2016), trustworthiness dimensions are likely to exert differential effects on employee outcomes such as voluntary turnover. One key issue for supervisor trustworthiness acting as a mediator between contract breach and voluntary turnover is whether a lack of trustworthiness suggests that breach was intentional (Lester et al., 2002; Morrison \& Robinson, 1997). This is because, according to attribution theories and related social psychology research (Kelley, 1973; Little et al., 2012; Rule et al., 2013; Zapata, Olsen, \& Martins, 2013), individuals take actions that are consistent with the meaning associated with their attributions. Thus, trustworthiness dimensions that indicate a voluntary contribution (i.e., a responsibility) of the supervisor for contract breach should lead to voluntary turnover while those that do not should not have the same deleterious effect.

We expect low supervisor benevolence and integrity (i.e., 'will do' factors), but not low ability (i.e., a 'can do' factor), to indicate intentional contract breach (Colquitt, Scott, \& LePine, 2007). These predictions are consistent with previous work in the field of betrayal and trust repair (Elangovan \& Shapiro, 1998; Tomlinson \& Mayer, 2009) that suggests that low benevolence and integrity, but not low ability, are associated with perceptions that trustees are responsible for their actions and willingly break their promises toward trustors. In effect, newcomers generally perceive supervisors as purposely deciding whether they care about subordinates' well-being, value their relationship with them, and demonstrate goodwill toward them (Elangovan \& Shapiro, 1998; Tomlinson \& Mayer, 2009). Thus, they should perceive benevolence as being intentional in nature. Similarly, newcomers should consider that supervisors have the power to decide whether 
they act in accordance with principles acceptable to them and respect their rights (Elangovan \& Shapiro, 1998; Tomlinson \& Mayer, 2009). As a result, they should also interpret supervisor integrity as reflecting purposeful or intentional behavior.

Taken together, these arguments suggest that, when newcomers experience contract breach, they may come to think that this has occurred due to a lack of benevolence and integrity on the part of their supervisor, as being low on these dimensions implies that one has willingly failed to fulfill one's obligations toward newcomers. As it is known that newcomers are liable to quick voluntary turnover decisions (e.g., Boswell, Boudreau, \& Tichy, 2005; Farber, 1994), it is thus likely that contract breach will result in voluntary turnover through perceptions of low supervisor benevolence and integrity. In contrast, supervisor ability should not act as a mediator since it is generally associated with involuntary contract breach (Elangovan \& Shapiro, 1998). Thus, we propose the following hypotheses.

Hypothesis 2a: Supervisor benevolence will mediate a positive relationship between psychological contract breach and voluntary turnover.

Hypothesis 2b: Supervisor integrity will mediate a positive relationship between psychological contract breach and voluntary turnover.

\section{Negative affectivity as a moderator}

Although the above discussion underlines the important role of attributions in explaining the role of supervisor trustworthiness dimensions in the psychological contract breach process, this process is also likely shaped by newcomers' dispositions (Martinko, Harvey, \& Dasborough, 2011; Saks \& Ashforth, 1997). Negative affectivity, which represents the tendency to experience negative emotions such as distress, fear, irritation, or guilt (Watson, Clark, \& Tellegen, 1988), is particularly relevant to consider as a moderator of contract breach's effects.

Indeed, high-negative affectivity individuals are more vigilant than their low-negative affectivity counterparts to signs of impending punishment or frustration (Judge \& Larsen, 2001). Essentially, individuals high in negative affectivity are thus more likely to view their new environment as hostile and threatening (Bowling, Hendricks, \& Wagner, 2008; Watson, Clark, \& Tellegen, 1988). They would expect negative things to happen and develop pessimistic views of the organization (Thoresen, Kaplan, Barsky, Warren, \& de Chermont, 2003). They are also more likely to ascribe 'malicious motives' to others (Penney \& Spector, 2005: 781). Similarly, high-negative affectivity individuals have been reported to perceive greater injustice (Thoresen et al., 2003). Thus, as they tend to prepare for the worst, newcomers with high negative affectivity may be less sensitive to the occurrence of negative events, such as psychological contract breach. As contract breach is consistent with their negative expectations, they should be less likely to seek explanations when it occurs and to attribute breach to low supervisor trustworthiness. Relatedly, supervisors' level of benevolence and integrity should not constitute major drivers of the decision to leave the organization among newcomers with high negative affectivity. Therefore, negative affectivity is expected to act as a 'reducer' of the relationship between breach and supervisor trustworthiness dimensions and of the indirect relationship between breach and voluntary turnover via supervisor benevolence and integrity.

In support of our reasoning, evidence from related domains suggests that high-negative affectivity individuals react less strongly to negative events or situations. For example, Begley and Lee (2005) found that high-negative affectivity individuals reacted less strongly to negative changes in bonus awards, which these authors attributed to their negative expectations. Similarly, Fisher and Locke (1992) demonstrated that high-negative affectivity individuals were less likely to react to job dissatisfaction, whereas Lopina, Rogelberg, and Howell (2012) found these individuals to be less likely to re-evaluate the negative aspects of their job and leave the organization as a result. 
Our reasoning is also aligned with the fact that high-negative affectivity individuals tend to inhibit their behavior, especially in new environments, which is typical of newcomers' situation (Judge \& Larsen, 2001; Saks \& Ashforth, 1997). Thus, based on a met expectations hypothesis (Begley \& Lee, 2005; Wanous, Poland, Premack, \& Davis, 1992), high-negative affectivity newcomers should expect contract breaches to occur, hence should be less likely to question their supervisor's trustworthiness for these events, and ultimately leave the organization as a result. This leads to our remaining hypotheses.

Hypothesis 3a: Negative affectivity moderates the negative relationship between psychological contract breach and supervisor ability, such that this relationship is weaker at high levels of negative affectivity (vs. stronger at low levels of negative affectivity).

Hypothesis 3b: Negative affectivity moderates the negative relationship between psychological contract breach and supervisor benevolence, such that this relationship is weaker at high levels of negative affectivity (vs. stronger at low levels of negative affectivity).

Hypothesis 3c: Negative affectivity moderates the negative relationship between psychological contract breach and supervisor integrity, such that this relationship is weaker at high levels of negative affectivity (vs. stronger at low levels of negative affectivity).

Hypothesis 4a: Negative affectivity moderates the indirect relationship between psychological contract breach and voluntary turnover through supervisor benevolence such that this indirect relationship is weaker at high levels of negative affectivity (vs. stronger at low levels of negative affectivity).

Hypothesis 4b: Negative affectivity moderates the indirect relationship between psychological contract breach and voluntary turnover through supervisor integrity such that this indirect relationship is weaker at high levels of negative affectivity (vs. stronger at low levels of negative affectivity).

\section{Method}

\section{Sample and procedure}

We contacted organizations and professional or alumni associations in Canada likely to have newcomers among their members. Five organizations and associations, representing an overall number of 26,553 individuals, agreed to participate in the study. More specifically, these organizations and associations agreed that we contact their employees/members to invite them to complete the study's questionnaires on a voluntary basis. Prospective participants were contacted through emails that described the study's purpose and the target population (i.e., newcomers). Emails also specified that responses would remain confidential. The Time 1 questionnaire included, among others, measures of psychological contract breach, negative affectivity, supervisor trustworthiness, and demographics. In total, 935 individuals responded to the Time 1 questionnaire on a voluntary basis. Among them, 272 were excluded because they reported having more than 1 year of tenure, which is the conventional cut-off for being considered as a newcomer (see Bauer, Bodner, Erdogan, Truxillo, \& Tucker, 2007). Eight months after Time 1, the same participants who had completed the Time 1 questionnaire were surveyed about their organizational membership status (i.e., voluntary turnover). A total of 243 individuals provided information related to voluntary turnover. In the final sample $(N=243)$, most respondents were women $(79 \%)$ and the average age was 27.9 years $(\mathrm{SD}=6.4)$. Respondents mostly worked full-time $(58 \%)$ and most held a university degree (76\%). About half $(53 \%)$ of them have been graduated since less than 1 year. The most common types of occupations/jobs in the sample were healthcare 
jobs, including nurses, nurse assistants, physiotherapists, physicians, medical technologists, and medical archivists (26.3\%), and law-related occupations, including lawyers (18.1\%). Most participants (97\%) responded to the French version of the questionnaires.

We checked whether sample attrition led to non-random sampling across time (Goodman \& Blum, 1996). Using logistic regression, we tested whether the probability of answering the follow-up questionnaire was predicted by Time 1 psychological contract breach, supervisor trustworthiness dimensions, negative affectivity, and demographics (gender, age, tenure, type of newcomer [recent graduate vs. seasoned worker], language, and dummy-coded organization/ association membership variables). The result of the regression model predicting the probability of remaining in the sample at Time 2 was significant $\left(\Delta\right.$ Nagelkerke $\left.R^{2}=.07, p<.01\right)$. Three individual predictors, psychological contract breach, supervisor ability, and language, were significant $(B=-.28, p<.01 ; B=-.37, p<.05 ; B=1.05, p<.05)$. This suggests that sample attrition was not entirely random. We later discuss this as a limitation.

\section{Measures}

Participants recruited for the study completed all the measures. Well-established, validated scales were used to measure the study's variables. We translated English-language measures into French using a standard translation-back-translation procedure (Brislin, 1980). A 5-point scale (1 = strongly disagree; 5 = strongly agree) was used for all measures, except for the negative affectivity measure, for which items were answered on a scale ranging from 1 (very slightly or not at all) to 5 (extremely).

\section{Psychological contract breach}

Robinson and Morrison's (2000) 5-item scale was used to measure contract breach (e.g., 'I have not received everything promised to me in exchange for my contributions'). In this study, this scale displayed excellent reliability $(\alpha=.96)$. The reliability obtained in this study is similar to the reliability reported in Robinson and Morrison's study $(\alpha=.92)$ and in recent studies using this scale (e.g., Rosen et al., 2009; $\alpha=.91$ ).

\section{Supervisor trustworthiness}

Supervisor trustworthiness dimensions were measured using Mayer and Davis's (1999) 17-item scale (e.g., ability: 'My supervisor is well qualified'; 6 items, $\alpha=.89$; benevolence: 'My supervisor is very concerned about my welfare'; 5 items, $\alpha=.90$; integrity: 'My supervisor has a strong sense of justice'; 6 items, $\alpha=.86$ ). The very good reliabilities obtained for the three trustworthiness dimensions in this study are similar to those reported by Mayer and Davis $(1999 ; \alpha s=.85$ and .88 for ability, $\alpha s=.87$ and .89 for benevolence, and $\alpha s=.82$ and .88 for integrity) and in recent research using the same scales (e.g., Holtz, De Cremer, Hu, Kim, \& Giacalone, 2020: $\alpha$ s = .94, .96, and .96 for ability, $\alpha s=.92, .94$, and .93 for benevolence, and $\alpha s=.96, .97$, and .97 for integrity).

\section{Negative affectivity}

We used a 10-item scale from Watson, Clark, and Tellegen (1988) to assess negative affectivity (e.g., 'upset'). These items were preceded by the phrase 'In general, I feel...'. The scale displayed strong reliability in this study $(\alpha=.84)$. The reliability obtained in this study is comparable to the reliability reported by Watson, Clark, and Tellegen (1988) when using similar time instructions (i.e., 'In general'; $\alpha=.87$ ). It is also similar to the reliability reported in recent research using Watson, Clark, and Tellegen's (1988) scale and same 'In general' time instruction (e.g., Vandenberghe et al., 2019; $\alpha=.85$ ).

\section{Voluntary turnover}

Voluntary turnover was defined as a dichotomous outcome classifying any respondent either as a stayer (0) or a voluntary leaver (1) at Time 2 . This treatment of the voluntary turnover variable is consistent with research practices (e.g., Arnold, Van Iddekinge, Campion, Bauer, \& Campion, 
2020; Clinton \& Guest, 2014; Lopina, Rogelberg, \& Howell, 2012). Excluding cases of involuntary turnover $(n=7)$, the voluntary turnover rate was $15.2 \%$ in our sample.

\section{Control variables}

We controlled for age, gender, type of newcomer, and organizational tenure because these variables were previously found to be related to the study's variables or were found to be relevant in socialization contexts (Dirks \& Ferrin, 2002; Grant \& Sumanth, 2009; Griffeth, Hom, \& Gaertner, 2000; Saks, Uggerslev, \& Fassina, 2007).

\section{Results}

\section{Confirmatory factor analyses}

The dimensionality of our data was examined through confirmatory factor analysis using LISREL 8.80 (Jöreskog \& Sörbom, 2006) and the maximum likelihood method of estimation with a variance/covariance matrix as input. We compared our hypothesized model to more parsimonious models using $\chi^{2}$ difference tests (Bentler \& Bonnett, 1980). The hypothesized five-factor model yielded a good fit to the data, $\chi^{2}(454)=1,009.98, p<.001$, RMSEA $=.071$, CFI $=.96$, NNFI $=.96, \mathrm{SRMR}=.074$, and also improved significantly over more parsimonious four-factor models $\left(\Delta \chi^{2}=140.76-801.83, \Delta d f=4, p<.001\right)$ (Hu \& Bentler, 1999). Our constructs were thus distinguishable.

\section{Descriptive statistics and intercorrelations}

Descriptive statistics and intercorrelations are presented in Table 1. All variables displayed good internal consistency $(\alpha s>.70)$. Contract breach was negatively related to supervisor ability ( $r$ $=-.37, p<.001)$, benevolence $(r=-.50, p<.001)$, and integrity $(r=-.55, p<.001)$. Contract breach was also positively related to voluntary turnover $(r=.16, p<.05)$. Supervisor benevolence and integrity were both negatively related to voluntary turnover $(r=-.15, p<.05$, and $r=-.19, p$ $<.01$, respectively). Finally, negative affectivity was negatively related to supervisor benevolence $(r$ $=-.13, p<.05)$ and integrity $(r=-.12, p<.05)$, and positively related to voluntary turnover $(r$ $=.10, p<.05)$.

\section{Hypothesis tests}

\section{Hypotheses $1 a-c$}

Multiple regression, with controls entered at Step 1, was used to test Hypotheses 1a-c. As can be seen from Table 2 (Model $2 \mathrm{~s}$ ), contract breach significantly and negatively predicted supervisor ability $(\beta=-.36, p<.001)$, benevolence $(\beta=-.50, p<.001)$, and integrity $(\beta=-.54, p<.001)$. Therefore, Hypotheses $1 \mathrm{a}-\mathrm{c}$ are supported.

\section{Hypotheses $2 a-b$}

As a preliminary step before testing Hypotheses $2 a-b$, we used logistic regression to examine if supervisor integrity and supervisor benevolence predicted voluntary turnover, over and above control variables (Step 1) and contract breach (Step 2) (see Table 3) (Jaccard, 2001; Liao, 1994; Menard, 2002). In Step 3, supervisor integrity significantly and negatively predicted voluntary turnover $(B=-.68, p<.05)$ while supervisor benevolence did not $(B=-.38, n s)$ (see Table 3 , Model 3s). As we already know that contract breach is negatively related to supervisor integrity ( $\beta$ $=-.54, p<.001$; Table 2 ), we can now examine whether its indirect effect on voluntary turnover through supervisor integrity is significant. Consistent with Preacher and Hayes (2008), we used a bootstrap approach to test this indirect effect. The bias-corrected confidence interval (CI), as obtained from 5,000 bootstrap estimates, for the indirect effect of contract breach on voluntary 
Table 1. Descriptive statistics and intercorrelations among study variables

\begin{tabular}{|c|c|c|c|c|c|c|c|c|c|c|c|}
\hline Variable & M & SD & 1 & 2 & 3 & 4 & 5 & 6 & 7 & 8 & 9 \\
\hline 1. Psychological contract breach & 1.99 & .91 & (.96) & & & & & & & & \\
\hline 2. Supervisor ability & 4.17 & .65 & $-.37^{\star \star \star}$ & $(.89)$ & & & & & & & \\
\hline 3. Supervisor benevolence & 3.76 & .74 & $-.50^{\star \star \star}$ & $.57^{\star \star \star}$ & $(.90)$ & & & & & & \\
\hline 4. Supervisor integrity & 3.98 & .68 & $-.55^{\star \star \star}$ & $.75^{\star \star \star}$ & $.80^{\star \star \star}$ & $(.86)$ & & & & & \\
\hline 5. Negative affectivity & 1.87 & .58 & $.12^{*}$ & -.02 & $-.13^{\star}$ & $-.12^{\star}$ & $(.84)$ & & & & \\
\hline 6. Voluntary turnover & .15 & .36 & $.16^{\star}$ & -.10 & $-.15^{\star}$ & $-.19^{\star \star}$ & $.10^{\star}$ & - & & & \\
\hline 7. Age & 27.88 & 6.40 & -.10 & .05 & .12 & $.14^{\star}$ & $-.14^{\star}$ & .00 & - & & \\
\hline 8. Gender & .79 & .41 & .09 & $-.17^{\star \star}$ & -.04 & -.12 & .06 & -.01 & $-.18^{\star \star}$ & - & \\
\hline 9. Type of newcomer & .52 & .50 & .05 & -.07 & -.07 & $-.16^{\star}$ & .06 & -.01 & $-.47^{\star \star \star}$ & .08 & - \\
\hline 10. Organizational tenure (months) & 6.81 & 3.44 & .12 & -.07 & -.06 & -.06 & -.05 & -.00 & -.05 & .02 & -.04 \\
\hline
\end{tabular}

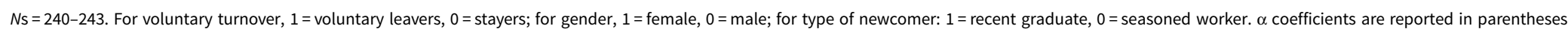
along the diagonal.

${ }^{\star} p<.05 ;{ }^{\star \star} p<.01 ;{ }^{\star \star \star} p<.001$ 
Table 2. Results of moderated multiple regression analyses for supervisor trustworthiness dimensions

\begin{tabular}{|c|c|c|c|c|c|c|c|c|c|c|}
\hline \multirow[b]{2}{*}{ Step } & \multirow[b]{2}{*}{ Variable(s) entered } & \multicolumn{3}{|c|}{ Supervisor ability } & \multicolumn{3}{|c|}{ Supervisor benevolence } & \multicolumn{3}{|c|}{ Supervisor integrity } \\
\hline & & Model 1 & Model 2 & Model 3 & Model 1 & Model 2 & Model 3 & Model 1 & Model 2 & Model 3 \\
\hline \multirow[t]{4}{*}{1} & Age & -.01 & -.04 & -.04 & .10 & .05 & .05 & .06 & .02 & .02 \\
\hline & Gender & $-.17^{\star}$ & $-.15^{\star}$ & $-.13^{*}$ & -.02 & .02 & .04 & -.09 & -.05 & -.04 \\
\hline & Type of newcomer & -.06 & -.05 & -.06 & -.03 & -.02 & -.03 & -.12 & -.11 & $-.12^{\star}$ \\
\hline & Organizational tenure (months) & -.07 & -.02 & -.01 & -.06 & -.00 & .01 & -.06 & .00 & .01 \\
\hline \multirow[t]{2}{*}{2} & Psychological contract breach (PCB) & & $-.36^{\star \star \star}$ & $-.39^{\star \star \star}$ & & $-.50^{\star \star \star}$ & $-.53^{\star \star \star}$ & & $-.54^{\star \star \star}$ & $-.57^{\star \star \star}$ \\
\hline & Negative affectivity (NA) & & .03 & .03 & & -.05 & -.04 & & -.01 & -.01 \\
\hline \multirow[t]{2}{*}{3} & $\mathrm{PCB} \times \mathrm{NA}$ & & & $.22^{\star \star \star}$ & & & $.26^{\star \star \star}$ & & & $.21^{\star \star \star}$ \\
\hline & $\Delta R^{2}$ & .04 & $.12^{\star \star \star}$ & $.05^{\star \star \star}$ & .02 & $.25^{\star \star \star}$ & $.06^{\star \star \star}$ & $.04^{\star}$ & $.28^{\star \star \star}$ & $.05^{\star \star \star}$ \\
\hline
\end{tabular}

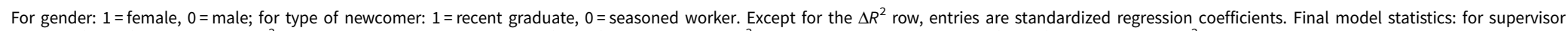
ability: $F(7,232)=8.64, p<.001, R^{2}=.21$; for supervisor benevolence: $F(7,232)=16.16, p<.001, R^{2}=.33$; for supervisor integrity: $F(7,232)=19.36, p<.001, R^{2}=.37$.

${ }^{\star} p<.05 ;{ }^{\star \star \star} p<.001$. 
Table 3. Results of logistic regression analyses for voluntary turnover using supervisor benevolence and integrity as mediators

\begin{tabular}{|c|c|c|c|c|c|c|c|c|c|c|c|c|c|}
\hline \multirow[b]{2}{*}{ Step } & \multirow[b]{2}{*}{ Variable(s) entered } & \multicolumn{6}{|c|}{ Supervisor benevolence } & \multicolumn{6}{|c|}{ Supervisor integrity } \\
\hline & & B & $\begin{array}{c}\operatorname{Exp} \\
(B)\end{array}$ & B & $\begin{array}{c}\text { Exp } \\
(B)\end{array}$ & B & $\begin{array}{c}\operatorname{Exp} \\
(B)\end{array}$ & B & $\begin{array}{c}\operatorname{Exp} \\
(B)\end{array}$ & B & $\begin{array}{l}\text { Exp } \\
(B)\end{array}$ & B & $\begin{array}{c}\text { Exp } \\
(B)\end{array}$ \\
\hline \multirow[t]{3}{*}{1} & Age & -.00 & .99 & .00 & 1.00 & .00 & 1.00 & -.00 & .99 & .00 & 1.00 & .00 & 1.00 \\
\hline & Gender & -.06 & .94 & -.14 & .87 & -.12 & .89 & -.06 & .94 & -.14 & .87 & -.23 & .80 \\
\hline & Organizational tenure (months) & -.00 & .99 & -.02 & .98 & -.02 & .98 & -.00 & .99 & -.02 & .98 & -.02 & .98 \\
\hline 2 & Psychological contract breach & & & $.45^{\star}$ & 1.57 & .30 & 1.35 & & & $.45^{\star}$ & 1.57 & .20 & 1.22 \\
\hline \multirow[t]{2}{*}{3} & Supervisor benevolence/integrity & & & & & -.38 & .68 & & & & & $-.68^{\star}$ & .51 \\
\hline & $\Delta R^{2}$ & .00 & & $.04^{\star}$ & & .06 & & .00 & & $.04^{\star}$ & & $.07^{\star}$ & \\
\hline
\end{tabular}

For gender: 1 = female, $0=$ male; for type of newcomer: $1=$ recent graduate, $0=$ seasoned worker. The $\Delta R^{2}$ row includes Nagelkerke $\Delta R^{2}$ values. Model statistics for supervisor benevolence: Model $1: \chi^{2}(4, N=240)$ $=.05, n s,-2 \mathrm{LL}=206.92$, constant $=-1.48$; Model 2: $\chi^{2}(5, N=240)=5.70, p<.05,-2 \mathrm{LL}=200.60$, constant $=-2.38$; Model $3: \chi^{2}(6, N=240)=7.68, n s,-2 \mathrm{LL}=198.66$, constant $=-.75$. Model statistics for superviso

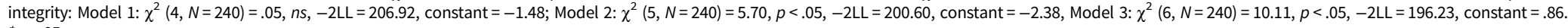
${ }^{*} p<.05$. 
turnover through supervisor integrity excluded zero (.27, 95\% CI .02-.56), indicating a significant indirect effect. In contrast, the bias-corrected CI for the indirect effect of contract breach on voluntary turnover through supervisor benevolence did not exclude zero (.16, 95\% CI -.06 to .43), indicating a non-significant indirect effect. Therefore, Hypothesis $2 \mathrm{a}$ is not supported while Hypothesis $2 \mathrm{~b}$ is supported.

\section{Hypotheses $3 a-c$}

We used moderated multiple regression to examine Hypotheses 3a-c. Following Aiken and West (1991), Aguinis and Gottfredson (2010), and Jaccard and Turrisi (2003), contract breach and negative affectivity were centered prior to the calculation of their interaction term. Results reported in Table 2 (Model 3s) show that contract breach and negative affectivity interacted in the prediction of supervisor ability $\left(\beta=.22, p<.001, \Delta R^{2}=.05\right)$, benevolence $(\beta=.26, p<.001$, $\left.\Delta R^{2}=.06\right)$, and integrity $\left(\beta=.21, p<.001, \Delta R^{2}=.05\right)$. To illustrate these interactions (Aguinis \& Gottfredson, 2010), we plotted the regression line of trustworthiness dimensions on contract breach at 1 SD below and 1 SD above the mean of negative affectivity (see Figures 2-4). Simple slope analyses showed that contract breach was significantly and negatively related to supervisor ability, benevolence, and integrity at both high $(t[232]=-2.03, p<.001, t[232]=-$ $3.81, p<.001$, and $t[232]=-4.60, p<.001$, respectively) and low $(t[232]=-7.05, p<.001$, $t[232]=-10.44, p<.001$, and $t[232]=-9.80, p<.001$, respectively) levels of negative affectivity. However, these relationships were significantly weaker at high levels of negative affectivity $(t[232]=3.72, p<.05, t[232]=4.91, p<.05$, and $t[232]=4.11, p<.001$, respectively). Therefore, Hypotheses $3 \mathrm{a}, 3 \mathrm{~b}$, and $3 \mathrm{c}$ are supported.

\section{Hypotheses $4 a-b$}

We followed Preacher, Rucker, and Hayes's (2007; see also Hayes, 2015) moderated mediation analytical procedure to examine Hypotheses $4 \mathrm{a}-\mathrm{b}$. Negative affectivity did not moderate the indirect effect of contract breach on voluntary turnover through supervisor benevolence $(-.13$, $95 \%$ CI -.43 to .05$)$, this indirect effect being non-significant at both high $(.09,95 \%$ CI -.04 to .28$)$ and low $(.24,95 \%$ CI -.11 to .66) levels of negative affectivity. Hypothesis 4 a is thus not supported. In contrast, the indirect effect of contract breach on voluntary turnover through supervisor integrity was significantly moderated by negative affectivity $(-.18,95 \% \mathrm{CI}-.46$ to $-.02)$, this indirect effect being weaker at high $(.18,95 \%$ CI .01 to .47$)$ than at low $(.38,95 \%$ CI .002 to .77) levels of negative affectivity. Hypothesis $4 \mathrm{~b}$ is thus supported. ${ }^{1}$

\section{Discussion}

Aiming to offer new insights into the psychological contract breach-voluntary turnover relationship, this study found a negative relationship between contract breach and the three dimensions of supervisor trustworthiness, i.e., ability, benevolence, and integrity, and further demonstrated that contract breach was positively related to voluntary turnover through lower supervisor integrity. In addition, these relationships were found to be weaker at high levels of negative affectivity. These findings bear important implications for theory and practice which are outlined below.

\section{Theoretical implications and directions for future research}

First, our study suggests that psychological contract breach is likely to undermine newcomers' perception that they can count on their supervisor's ability, benevolence, and integrity. Consistent with an attributional perspective, these negative relationships suggest that newcomers

\footnotetext{
${ }^{1}$ We rerun all analyses including the five organizations/associations as dummy-coded controls. None affected the significance of the findings. These analyses are available on request.
} 
14 Émilie Lapointe and Christian Vandenberghe

Figure 2. Interaction between psychological contract breach and negative affectivity in predicting supervisor ability.

Figure 3. Interaction between psychological contract breach and negative affectivity in predicting supervisor benevolence.
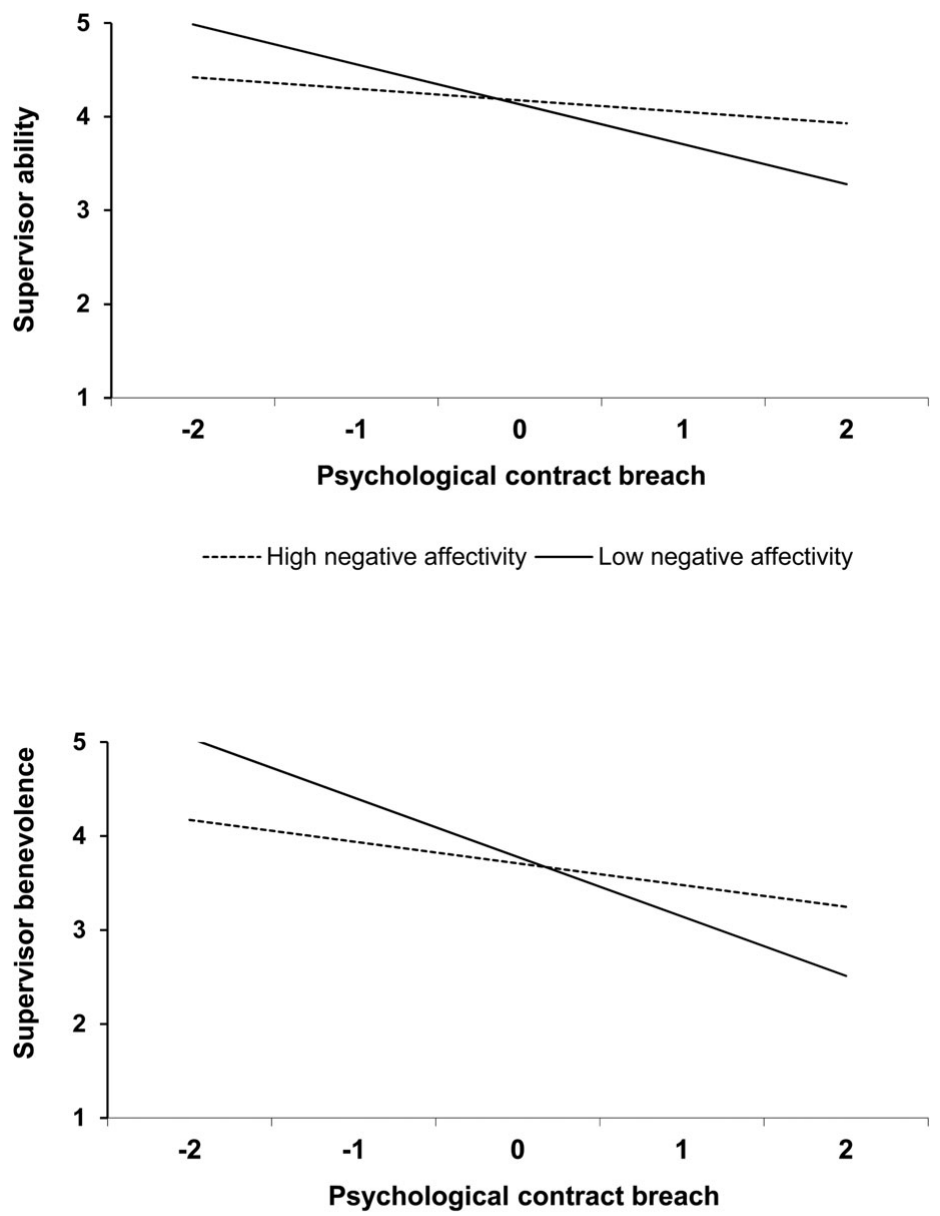

------ High negative affectivity —_ Low negative affectivity

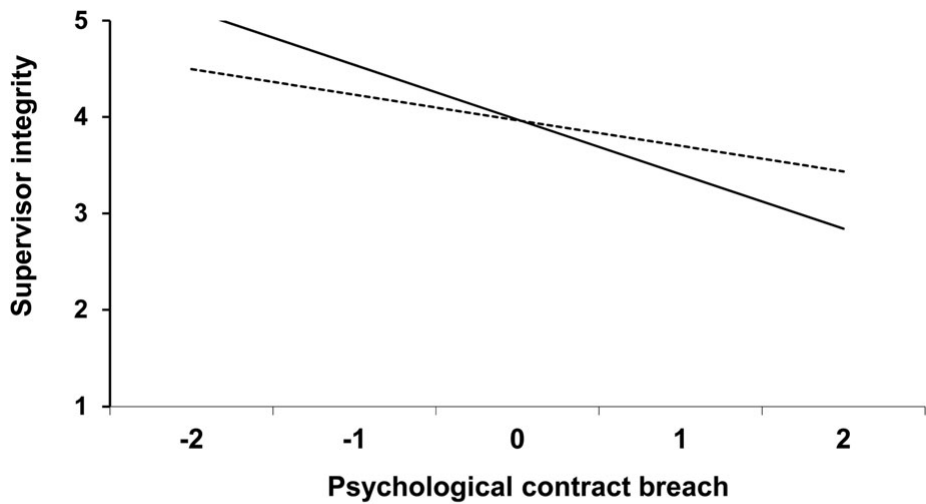

Figure 4. Interaction between psychological contract breach and negative affectivity in predicting supervisor integrity. 
attribute, at least in part, breaches to a lack of trustworthiness on the part of the supervisor. As such, results reinforce the key role played by supervisors in the breach process $(\mathrm{Ng}$, Feldman, \& Butts, 2014). Besides, just as breach is a subjective phenomenon (Morrison \& Robinson, 1997; Robinson, 1996), judgments of trustworthiness reflect subjective impressions (Rule et al., 2013). Considering this and as individuals may attribute different causes to breach depending on their past experiences (Kelley \& Michela, 1980), an interesting extension to this study would be to assess how newcomers' history of breaches with former employers affects the attributions they make following breaches to the psychological contract, and the role they see supervisors playing in the breach process (Robinson \& Morrison, 2000).

Second, this study identified supervisor integrity as a key mediator of the breach-voluntary turnover relationship. This finding suggests that a lack of integrity of the supervisor is interpreted by newcomers as a voluntary contribution to breach (Lester et al., 2002; Morrison \& Robinson, 1997). Such attribute of the supervisor would mean that he or she has knowingly broken the psychological contract, and, as this is perceived as a form of betrayal (Elangovan \& Shapiro, 1998), it makes newcomers more inclined to leave the organization. Furthermore, newcomers who come to think that their supervisor's words and actions are inconsistent or unpredictable (i.e., low integrity) probably experience heightened uncertainty and more readily question the value of maintaining organizational membership following breach events. Considering that reducing uncertainty is a major driver of newcomers' behavior, such experiences likely lead to premature voluntary turnover (Bauer et al., 2007).

In contrast, we did not find support for a mediating effect of supervisor benevolence. It might be that the assessment of supervisor's benevolence, because it is mainly established through repeated interactions (Mayer, Davis, \& Schoorman, 1995), takes more time to develop and show effects on outcome variables. Therefore, newcomers who do not feel cared about by their supervisor (i.e., benevolence) may not feel threatened and would not question their organizational membership in the short-term, which would explain the absence of a relationship between supervisor benevolence and voluntary turnover in this study. On the contrary, in the course of organizational socialization, newcomers are likely to indirectly learn more about supervisors' integrity (e.g., through informal networks; Mayer, Davis, \& Schoorman, 1995), which is consistent with the significant relationship between integrity and voluntary turnover. In this regard, our study also emphasizes the importance of distinguishing the three trustworthiness dimensions (Colquitt, Scott, \& LePine, 2007; Legood, Thomas, \& Sacramento, 2016; see also Weiss, Michels, Burgmer, Mussweiler, Ockenfels, \& Hofmann, 2020). As a future study, it would be worth testing the mediating effect of supervisor integrity in samples of regular employees, as it is unclear whether and how relationship duration influences the results (Dirks \& Ferrin, 2002; Frazier, Tupper, \& Fainshmidt, 2016; Pate, Morgan-Thomas, \& Beaumont, 2012).

Third, the moderating effect of negative affectivity found in this study is consistent with the premise that individuals with high levels of negative affectivity, as they tend to get prepared for negative fallouts (Begley \& Lee, 2005; Judge \& Larsen, 2001), are less reactive to negative events compared to individuals with low negative affectivity. In doing so, this study helps clarify the role of trait affect in attributional processes (Douglas \& Martinko, 2001). Specifically, highnegative affectivity newcomers were found to be less inclined to attribute breaches to a lack of supervisor trustworthiness and less likely to leave as a result. This reverse-buffering effect is consistent with a met expectations account of negative affectivity's workings (Wanous et al., 1992). Indeed, high-negative affectivity individuals do not have their expectations violated when they experience contract breaches, hence react less negatively to these events. Note however that although they are less likely to act following a negative event (e.g., Lopina, Rogelberg, \& Howell, 2012), these individuals are not necessarily committed to their organization or less likely to think about quitting (Cropanzano, James, \& Konovsky, 1993). Given this, future studies should examine the multiple mechanisms through which negative affectivity intervenes in the withdrawal process. 
Although our findings are consistent with a met expectations interpretation of negative affectivity's effects, other research has suggested that 'negative affectivity may act as a vulnerability factor' (Lazuras, Rodafinos, Matsiggos, \& Stamatoulakis, 2009: 1076). That is, high-negative affectivity individuals may perceive job stressors (e.g., psychological contract breach) more intensely and subsequently develop more negative reactions to stress (Spector, Zapf, Chen, \& Frese, 2000; see also Penney \& Spector, 2005; Walker, Van Jaarsveld, \& Skarlicki, 2014). Meta-analytic reviews have indeed reported negative affectivity to be positively related to strain and other stress responses (Alarcon, Eschleman, \& Bowling, 2009; Ng \& Sorensen, 2009). Yet, our results do not support the idea that negative affectivity would act as a vulnerability factor in the context of the relationship between contract breach and supervisor trustworthiness. Indeed, the correlation between negative affectivity and contract breach was rather weak in absolute terms $(r=.12, p<.05$; see Table 1) and the effects of negative affectivity on supervisor trustworthiness dimensions were non-significant (see Table 2). This may be because perceptions of supervisor trustworthiness are more cognitive in nature and do not represent stress reactions per se. Such perceptions may be more influenced by the extent to which contract breach comes as a surprise in the eyes of employees. Further research is required to elucidate this question.

\section{Limitations}

This study has limitations. First, although the variety of occupations represented in our sample is desirable for generalization purposes, we do not know if participants were representative of the organization/association they belonged to. Second, even if our 1-year or less of tenure criterion was similar to previous studies (see Bauer et al., 2007), the time period during which someone is a 'newcomer' is probably variable and context-specific. Third, sample attrition between measurement times was not entirely random. Newcomers experiencing low psychological contract breach were more likely to drop from the study. This may be due to individuals experiencing high levels of breach leaving their organization sooner, making our study rather conservative regarding the effects of breach. Fourth, all variables except voluntary turnover were measured at the same point in time, which raises common method variance concerns. However, tests of interaction effects, such as those involving negative affectivity, are not positively biased by method variance (Siemsen, Roth, \& Oliveira, 2010). Fifth, the fact that data on psychological contract breach and supervisor trustworthiness were collected at the same time limits our ability to draw causal inferences. Although the theoretical framework used in this study suggests the opposite, it remains possible for supervisor trustworthiness to influence psychological contract breach, rather than the reverse. More sophisticated longitudinal designs would be required in the future to palliate to this limitation and draw firmer conclusions about the direction of the relationships between the study's variables.

Sixth, trustworthiness dimensions were highly correlated $(r s=.57-.80)$. However, this study's results indicate that these dimensions were distinguishable and not interchangeable predictors of voluntary turnover. Moreover, there is reason to distinguish these dimensions from a theoretical perspective because they evoke distinct attributions regarding the role played by supervisors in breach events. Finally, it should be noted that, as the study was conducted among a sample of Canadian newcomers recruited via the organization or association they belonged to, it is unclear whether the results would generalize across samples and settings. We invite researchers to seek to replicate this study's findings in different cultural contexts (e.g., China; Lo \& Aryee, 2003) and industries (e.g., the public sector; Welander, Blomberg, \& Isaksson, 2020) to examine their generalizability.

\section{Practical implications}

This study's findings recall that supervisors should examine the promises they have knowingly or unknowingly conveyed to newcomers and try to fulfill these as much as possible (Morsch, Dijk, \& 
Kodden, 2020; Solberg, Lapointe, \& Dysvik, 2020; Welander, Blomberg, \& Isaksson, 2020; Woodrow \& Guest, 2020). Since supervisor integrity is particularly critical, policies to encourage the integrity of supervisors and training activities supporting the enactment of fair and ethical human resource practices seem warranted (Byrne, Pitts, Chiaburu, \& Steiner, 2011; Pate, Morgan-Thomas, \& Beaumont, 2012; see also Breuer, Hüffmeier, Hibben, \& Hertel, 2020; Holtz et al., 2020; Nedkovski, Guerci, De Battisti, \& Siletti, 2017). The establishment of effective communication channels and practices fostering supervisor-subordinate interactions could also help to avoid false impressions of low integrity (Rule et al., 2013; see also Holtz et al., 2020). Regarding the influence of negative affectivity, Holtom, Burton, and Crossley (2012) state that individual dispositions inform how supervisors might interact with specific employees. Supervisors should try to anticipate and, where appropriate, strategically manage the interpretation of certain events to maintain positive attitudes among employees. Supervisors may also seek to involve high-negative affectivity newcomers in developing solutions to potential contract breaches in order to make them, not just employees that stay in the organization, but good organizational citizens (Holtom, Burton, \& Crossley, 2012).

\section{References}

Aguinis, H., \& Gottfredson, R. K. (2010). Best-practice recommendations for estimating interaction effects using moderated multiple regression. Journal of Organizational Behavior, 31, 776-786. https://doi.org/10.1002/job.686.

Aiken, L. S., \& West, S. G. (1991). Multiple regression: Testing and interpreting interactions. Thousand Oaks: Sage Publications.

Alarcon, G., Eschleman, K. J., \& Bowling, N. A. (2009). Relationships between personality variables and burnout: A meta-analysis. Work and Stress, 23, 244-263. https://doi.org/10.1080/02678370903282600.

Arnold, J. D., Van Iddekinge, C. H., Campion, M. C., Bauer, T. N., \& Campion, M. A. (2020). Welcome back? Job performance and turnover of boomerang employees compared to internal and external hires. Journal of Management. Advance online publication. https://doi.org/10.1177/0149206320936335.

Bauer, T. N., Bodner, T., Erdogan, B., Truxillo, D. M., \& Tucker, J. S. (2007). Newcomer adjustment during organizational socialization: A meta-analytic review of antecedents, outcomes, and methods. Journal of Applied Psychology, 92, 707-721. https://doi.org/10.1037/0021-9010.92.3.707.

Begley, T., \& Lee, C. (2005). The role of negative affectivity in pay-at-risk reactions: A longitudinal study. Journal of Applied Psychology, 90, 382-388. https://doi.org/10.1037/0021-9010.90.2.382.

Bentler, P. M., \& Bonnett, D. G. (1980). Significance tests and goodness of fit in the analysis of covariance structures. Psychological Bulletin, 88, 588-606. https://doi.org/10.1037/0033-2909.88.3.588.

Boswell, W. R., Boudreau, J. W., \& Tichy, J. (2005). The relationship between employee job change and job satisfaction: The honeymoon-hangover effect. Journal of Applied Psychology, 90, 882-892. https://doi.org/10.1037/0021-9010.90.5.882.

Bowling, N. A., Hendricks, E. A., \& Wagner, S. H. (2008). Positive and negative affectivity and facet satisfaction: A meta-analysis. Journal of Business and Psychology, 23, 115-125. https://doi.org/10.1007/s10869-008-9082-.

Breuer, C., Hüffmeier, J., Hibben, F., \& Hertel, G. (2020). Trust in teams: A taxonomy of perceived trustworthiness factors and risk-taking behaviors in face-to-face and virtual teams. Human Relations, 73, 3-34. https://doi.org/10.1177/ 0018726718818721 .

Brislin, R. W. (1980). Translation and content analysis of oral and written materials. In H. C. Triandis \& J. W. Berry (Eds.), Handbook of cross-cultural psychology: Vol. 2. Methodology (pp. 137-164). Boston, MA: Allyn and Bacon.

Byrne, Z., Pitts, V., Chiaburu, D., \& Steiner, Z. (2011). Managerial trustworthiness and social exchange with the organization. Journal of Managerial Psychology, 26, 108-122. https://doi.org/10.1108/02683941111102155.

Cassar, V., \& Briner, R. B. (2011). The relationship between psychological contract breach and organizational commitment: Exchange imbalance as a moderator of the mediating role of violation. Journal of Vocational Behavior, 78, 283-289. https:// doi.org/10.1016/j.jvb.2010.09.007.

Clinton, M. E., \& Guest, D. E. (2014). Psychological contract breach and turnover: Testing a multiple mediation model. Journal of Occupational and Organizational Psychology, 87, 200-207. https://doi.org/10.1111/joop.12033.

Colquitt, J. A., \& Rodell, J. B. (2011). Justice, trust, and trustworthiness: A longitudinal analysis integrating three theoretical perspectives. Academy of Management Journal, 54, 1183-1206. https://doi.org/10.5465/amj.2007.0572.

Colquitt, J. A., Scott, B. A., \& LePine, J. A. (2007). Trust, trustworthiness, and trust propensity: A meta-analytic test of their unique relationships with risk taking and job performance. Journal of Applied Psychology, 92, 909-927. https://doi.org/10. 1037/0021-9010.92.4.909.

Conway, N., \& Briner, R. B. (2002). A daily diary study of affective responses to psychological contract breach and exceeded promises. Journal of Organizational Behavior, 23, 287-302. https://doi.org/10.1002/job.139. 
Conway, N., Guest, D., \& Trenberth, L. (2011). Testing the differential effects of changes in psychological contract breach and fulfillment. Journal of Vocational Behavior, 79, 267-276. https://doi.org/10.1016/j.jvb.2011.01.003.

Coyle-Shapiro, J. A. M., \& Shore, L. M. (2007). The employee-organization relationship: Where do we go from here? Human Resource Management Review, 17, 166-179. https://doi.org/10.1016/j.hrmr.2007.03.008.

Cropanzano, R., James, K., \& Konovsky, M. A. (1993). Dispositional affectivity as a predictor of work attitudes and job performance. Journal of Organizational Behavior, 14, 595-606. https://doi.org/10.1002/job.4030140609.

Dabos, G. E., \& Rousseau, D. M. (2004). Mutuality and reciprocity in the psychological contracts of employees and employers. Journal of Applied Psychology, 89, 52-72. https://doi.org/10.1037/0021-9010.89.1.52.

De Vos, A., Buyens, D., \& Schalk, R. (2003). Psychological contract development during organizational socialization: Adaptation to reality and the role of reciprocity. Journal of Organizational Behavior, 24, 537-559. https://doi.org/10. 1002/job.205.

Dirks, K. T., \& Ferrin, D. L. (2002). Trust in leadership: Meta-analytic findings and implications for research and practice. Journal of Applied Psychology, 87, 909-927. https://doi.org/10.1037/0021-9010.87.4.611.

Douglas, S. C., \& Martinko, M. J. (2001). Exploring the role of individual differences in the prediction of workplace aggression. Journal of Applied Psychology, 86, 547-559. https://doi.org/10.1037/0021-9010.86.4.547.

Eberl, P., Ute, C., \& Möller, H. (2012). Socialising employees' trust in the organisation: An exploration of apprentices' socialisation in two highly trusted companies. Human Resource Management Journal, 22, 343-359. https://doi.org/10.1111/ 1748-8583.12003.

Elangovan, A. R., \& Shapiro, D. L. (1998). Betrayal of trust in organizations. Academy of Management Review, 23, 547-566. https://doi.org/10.5465/amr.1998.926626.

Farber, H. S. (1994). The analysis of interfirm worker mobility. Journal of Labor Economics, 12, 554-593. https://doi.org/10. 3386/w4262.

Fisher, C., \& Locke, E. A. (1992). The new look in job satisfaction theory and research. In J. Cranny, P. Smith \& E. F. Stone (Eds.), Job satisfaction: How people feel about their jobs and how it affects their performance (pp. 165-194). Lexington: Lexington Books.

Frazier, M. L., Johnson, P. D., Gavin, M., Gooty, J., \& Snow, D. B. (2010). Organizational justice, trustworthiness, and trust: A multifoci examination. Group \& Organization Management, 35, 39-76. https://doi.org/10.1177/1059601109354801.

Frazier, M. L., Tupper, C., \& Fainshmidt, S. (2016). The path(s) to employee trust in direct supervisor in nascent and established relationships: A fuzzy set analysis. Journal of Organizational Behavior, 37, 1023-1043. https://oi.org/10.1002/job. 2091.

Gardner, D. G., Huang, G. H., Niu, X., Pierce, J. L., \& Lee, C. (2015). Organization-based self-esteem, psychological contract fulfillment, and perceived employment opportunities: A test of self-regulatory theory. Human Resource Management, 54, 933-953. https://doi.org/10.1002/hrm.21648.

Goodman, J. S., \& Blum, T. C. (1996). Assessing the non-random sampling effects of subject attrition in longitudinal research. Journal of Management, 22, 627-652. https://doi.org/10.1177/014920639602200405.

Grant, A. M., \& Sumanth, J. J. (2009). Mission possible? The performance of prosocially motivated employees depends on manager trustworthiness. Journal of Applied Psychology, 94, 927-944. https://doi.org/10.1037/a0014391.

Griffeth, R. W., Hom, P. W., \& Gaertner, S. (2000). A meta-analysis of antecedents and correlates of employee turnover: Update, moderator tests, and research implications for the millennium. Journal of Management, 26, 463-488. https:// doi.org/10.1016/S0149-2063(00)00043-X.

Hayes, A. F. (2015). An index and test of linear moderated mediation. Multivariate Behavioral Research, 50, 1-22. https://doi. org/10.1080/00273171.2014.962683.

Heider, F. (1958). The psychology of interpersonal relations. New York, NY: Wiley.

Herriot, P., Manning, W. E. G., \& Kidd, J. M. (1997). The content of the psychological contract. British Journal of Management, 8, 151-162. http://dx.doi.org/10.1111/1467-8551.0047.

Holtom, B. C., Burton, J. P., \& Crossley, C. D. (2012). How negative affectivity moderates the relationship between shocks, embeddedness and worker behaviors. Journal of Vocational Behavior, 80, 434-443. https://doi.org/10.1016/j.jvb.2011.12.006.

Holtz, B. C., De Cremer, D., Hu, B., Kim, J., \& Giacalone, R. A. (2020). How certain can we really be that our boss is trustworthy, and does it matter? A metacognitive perspective on employee evaluations of supervisor trustworthiness. Journal of Organizational Behavior, 41, 587-605. https://doi.org/10.1002/job.2447.

Hu, L. T., \& Bentler, P. M. (1999). Cutoff criteria for fit indexes in covariance structure analysis: Conventional criteria versus new alternatives. Structural Equation Modeling: A Multidisciplinary Journal, 6, 1-55. https://doi.org/10.1080/ 10705519909540118.

Jaccard, J. (2001). Interaction effects in logistic regression. Thousand Oaks, CA: Sage Publications.

Jaccard, J., \& Turrisi, R. (2003). Interaction effects in multiple regression. Thousand Oaks, CA: Sage Publications.

Jöreskog, K. G., \& Sörbom, D. (2006). LISREL 8.80 for Windows [Computer software], Lincolnwood: Scientific Software International Inc.

Judge, T. A., \& Larsen, R. J. (2001). Dispositional affect and job satisfaction: A review and theoretical extension. Organizational Behavior and Human Decision Processes, 86, 67-98. https://doi.org/10.1006/obhd.2001.2973. 
Kelley, H. H. (1973). The process of causal attributions. American Psychologist, 28, 107-128. https://doi.org/10.1037/ h0034225.

Kelley, H. H., \& Michela, J. L. (1980). Attribution theory and research. Annual Review of Psychology, 31, 457-501. https://doi. org/10.1146/annurev.ps.31.020180.002325.

Lapointe, E., Vandenberghe, C., Ben Ayed, A. K., Schwarz, G., Tremblay, M., \& Chenevert, D. (2020). Social comparisons, self-conceptions, and attributions: Assessing the self-related contingencies in leader-member exchange relationships. Journal of Business and Psychology, 35, 381-402. https://doi.org/10.1007/s10869-019-09628-9.

Lazuras, L., Rodafinos, A., Matsiggos, G., \& Stamatoulakis, A. (2009). Perceived occupational stress, affective, and physical well-being among telecommunication employees in Greece. Social Science \& Medicine, 68, 1075-1081. https://doi.org/ 10.1016/j.socscimed.2008.12.020.

Legood, A., Thomas, G., \& Sacramento, C. (2016). Leader trustworthy behavior and organizational trust: The role of the immediate manager for cultivating trust. Journal of Applied Social Psychology, 46, 673-686. https://doi.org/10.1111/jasp.12394.

Lester, S. W., Turnley, W. H., Bloodgood, J. M., \& Bolino, M. C. (2002). Not seeing eye to eye: Differences in supervisor and subordinate perceptions of and attributions for psychological contract breach. Journal of Organizational Behavior, 23, 3956. https://doi.org/10.1002/job.126.

Liao, T. F. (1994). Interpreting probability models: Logit, probit, and other generalized linear models. Thousand Oaks, CA: Sage Publications.

Little, A. C., Roberts, S. C., Jones, B. C., \& DeBruine, L. M. (2012). The perception of attractiveness and trustworthiness in male faces affects hypothetical voting decisions differently in wartime and peacetime scenarios. Quarterly Journal of Experimental Psychology, 65, 2018-2032. https://doi.org/10.1080/17470218.2012.677048.

Lo, S., \& Aryee, S. (2003). Psychological contract breach in a Chinese context: An integrative approach. Journal of Management Studies, 40, 1005-1020. https://doi.org/10.1111/1467-6486.00368.

Lopina, E. C., Rogelberg, S. G., \& Howell, B. (2012). Turnover in dirty work occupations: A focus on pre-entry individual characteristics. Journal of Occupational and Organizational Psychology, 85, 396-406. https://doi.org/10.1111/j.2044-8325. 2011.02037.x.

Martinko, M. J., Harvey, P., \& Dasborough, M. T. (2011). Attribution theory in the organizational sciences: A case of unrealized potential. Journal of Organizational Behavior, 32, 144-149. https://doi.org/10.1002/job.690.

Matta, F. K., Sabey, T. B., Scott, B. A., Lin, S.-H. (J.), \& Koopman, J. (2020). Not all fairness is created equal: A study of employee attributions of supervisor justice motives. Journal of Applied Psychology, 105, 274-293. https://doi.org/10. 1037/apl0000440.

Mayer, R. C., \& Davis, J. H. (1999). The effect of the performance appraisal system on trust for management: A field quasi-experiment. Journal of Applied Psychology, 84, 123-136. https://doi.org/10.1037/0021-9010.84.1.123.

Mayer, R. C., Davis, J. H., \& Schoorman, F. D. (1995). An integrative model of organizational trust. Academy of Management Review, 20, 709-734. https://doi.org/10.5465/amr.1995.9508080335.

Menard, S. (2002). Applied logistic regression analysis (2nd ed.). Thousand Oaks, CA: Sage Publications.

Morrison, E. W., \& Robinson, S. L. (1997). When employees feel betrayed: A model of how psychological contract violation develops. Academy of Management Review, 22, 226-256. https://doi.org/10.5465/amr.1997.9707180265.

Morsch, J., Dijk, D., \& Kodden, B. (2020). The impact of perceived psychological contract breach, abusive supervision, and silence on employee well-being. Journal of Applied Business and Economics, 22, 37-53. https://doi.org/10.33423/jabe.v22i2. 2799.

Munyon, T. P., Jenkins, M. T., Crook, T. R., Edwards, J., \& Harvey, N. P. (2019). Consequential cognition: Exploring how attribution theory sheds new light on the firm-level consequences of product recalls. Journal of Organizational Behavior, 40, 587-602. https://doi.org/10.1002/job.2350.

Nedkovski, V., Guerci, M., De Battisti, F., \& Siletti, E. (2017). Organizational ethical climates and employee's trust in colleagues, the supervisor, and the organization. Journal of Business Research, 71, 19-26. https://doi.org/10.1016/j.jbusres.2016. 11.004 .

Nifadkar, S. S. (2020). Filling in the 'blank slate': Examining newcomers' schemas of supervisors during organizational socialization. Journal of Management, 46, 666-693. https://doi.org/10.1177/0149206318807288.

Ng, T. W. H., Feldman, D. C., \& Butts, M. M. (2014). Psychological contract breaches and employee voice behavior: The moderating effects of changes in social relationships. European Journal of Work and Organizational Psychology, 23, 537-553. https://doi.org/10.1080/1359432X.2013.766394.

Ng, T. W. H., \& Sorensen, K. L. (2009). Dispositional affectivity and work-related outcomes: A meta-analysis. Journal of Applied Social Psychology, 39, 1255-1287. https://doi.org/10.1111/j.1559-1816.2009.00481.x.

Pate, J., Morgan-Thomas, A., \& Beaumont, P. (2012). Trust restoration: An examination of senior managers' attempt to rebuild employee trust. Human Resource Management Journal, 22, 148-164. https://doi.org/10.1111/j.1748-8583.2012. 00194.x.

Payne, S. C., Culbertson, S. S., Lopez, Y. P., Boswell, W. R., \& Barger, E. J. (2015). Contract breach as a trigger for adjustment to the psychological contract during the first year of employment. Journal of Occupational and Organizational Psychology, 88, 41-60. https://doi.org/10.1111/joop.12077. 
Penney, L. M., \& Spector, P. E. (2005). Job stress, incivility, and counterproductive work behavior (CWB): The moderating role of negative affectivity. Journal of Organizational Behavior, 26, 777-796. https://doi.org/10.1002/job.336.

Preacher, K. J., \& Hayes, A. F. (2008). Asymptotic and resampling strategies for assessing and comparing indirect effects in multiple mediator models. Behavior Research Methods, 40, 879-891. https://doi.org/10.3758/BRM.40.3.879.

Preacher, K. J., Rucker, D. D., \& Hayes, A. F. (2007). Assessing moderated mediation hypotheses: Theory, methods, and prescriptions. Multivariate Behavioral Research, 42, 185-227. https://doi.org/10.1080/00273170701341316.

Puranik, H., Koopman, J., Vough, H. C., \& Gamache, D. L. (2019). They want what I've got (I think): The causes and consequences of attributing coworker behavior to envy. Academy of Management Review, 44, 424-449. https://doi.org/10.5465/ amr.2016.0191.

Robinson, S. (1996). Trust and breach of the psychological contract. Administrative Science Quarterly, 41, 574-599. https:// doi.org/10.2307/2393868.

Robinson, S. L., \& Morrison, E. W. (2000). The development of psychological contract breach and violation: A longitudinal study. Journal of Organizational Behavior, 21, 526-546. https://doi.org/10.1002/1099-1379(200008)21:5<525::AIDJOB40>3.0.CO;2-T.

Robinson, S. L., \& Rousseau, D. M. (1994). Violating the psychological contract: Not the exception but the norm. Journal of Organizational Behavior, 15, 245-259. https://doi.org/10.1002/job.4030150306.

Rosen, C. C., Chang, C. H., Johnson, R. E., \& Levy, P. E. (2009). Perceptions of the organizational context and psychological contract breach: Assessing competing perspectives. Organizational Behavior and Human Decision Processes, 108, $202-217$. https://doi.org/10.1016/j.obhdp.2008.07.003.

Rousseau, D. M. (1995). Psychological contracts in organizations: Understanding written and unwritten agreement. Thousand Oaks: Sage Publications.

Rousseau, D. M. (2001). Schema, promise and mutuality: The building blocks of the psychological contract. Journal of Occupational and Organizational Psychology, 74, 511-541. https://doi.org/10.1348/096317901167505.

Rousseau, D. M., Hansen, S. D., \& Tomprou, M. (2018). A dynamic phase model of psychological contract processes. Journal of Organizational Behavior, 39, 1081-1098. https://doi.org/10.1002/job.2284.

Rule, N. O., Krendl, A. C., Ivcevic, Z., \& Ambady, N. (2013). Accuracy and consensus in judgments of trustworthiness from faces: Behavioral and neural correlates. Journal of Personality and Social Psychology, 104, 409-426. https://doi.org/10.1037/ a0031050.

Saks, A. M., \& Ashforth, B. E. (1997). Organizational socialization: Making sense of past and present as a prologue for the future. Journal of Vocational Behavior, 51, 234-279. https://doi.org/10.1006/jvbe.1997.1614.

Saks, A. M., Uggerslev, K. L., \& Fassina, N. E. (2007). Socialization tactics and newcomer adjustment: A meta-analytic review and test of a model. Journal of Vocational Behavior, 70, 413-446. https://doi.org/10.1016/j.jvb.2006.12.004.

Searle, R. H., \& Dietz, G. (2012). Editorial: Trust and HRM: Current insights and future directions. Human Resource Management Journal, 22, 333-342. https://doi.org/10.1111/1748-8583.12006.

Shih, C. T., \& Chuang, C. H. (2013). Individual differences, psychological contract breach, and organizational citizenship behavior: A moderated mediation study. Asia Pacific Journal of Management, 30, 191-210. https://doi.org/10.1007/ s10490-012-9294-8.

Siemsen, E., Roth, A., \& Oliveira, P. (2010). Common method bias in regression models with linear, quadratic, and interaction effects. Organizational Research Methods, 13, 456-476. https://doi.org/10.1177/1094428109351241.

Solberg, E., Lapointe, E., \& Dysvik, A. (2020). You care about me, but can I count on you? Applying a psychological contract perspective to investigate what makes employees willing to be internally employable. International Journal of Human Resource Management, 31, 1157-1179. https://doi.org/10.1080/09585192.2020.1737832.

Spector, P. E., Zapf, D., Chen, P. Y., \& Frese, M. (2000). Why negative affectivity should not be controlled in job stress research: Don't throw out the baby with the bath water. Journal of Organizational Behavior, 21, 79-95. https://doi.org/ 10.1002/(SICI)1099-1379(200002)21:1<79::AID-JOB964>3.0.CO;2-G.

Tekleab, A. G., Orvis, K. A., \& Taylor, M. S. (2013). Deleterious consequences of change in newcomers' employer-based psychological contract obligations. Journal of Business Psychology, 28, 361-374. https://doi.org/10.1007/s10869-012-9277-2.

Thoresen, C. J., Kaplan, S. A., Barsky, A. P., Warren, C. R., \& de Chermont, K. (2003). The affective underpinnings of job perceptions and attitudes: A meta-analytic review and integration. Psychological Bulletin, 129, 914-945. https://oi.org/10. 1037/0033-2909.129.6.914.

Tomlinson, E. C., \& Mayer, R. C. (2009). The role of causal attribution dimensions in trust repair. Academy of Management Review, 34, 85-104. https://doi.org/10.5465/amr.2009.35713291.

Treadway, D. C., Hochwarter, W. A., Ferris, G. R., Kacmar, C. J., Douglas, C., Ammeter, A. P., \& Buckley, M. R. (2004). Leader political skill and employee reactions. Leadership Quarterly, 15, 493-513. https://doi.org/10.1016/j.leaqua.2004.05.004.

Turnley, W. H., \& Feldman, D. C. (1999). A discrepancy model of psychological contract violations. Human Resource Management Review, 9, 367-386. https://doi.org/10.1016/S1053-4822(99)00025-X.

Vandenberghe, C., Panaccio, A., Bentein, K., Mignonac, K., Roussel, P., \& Ben Ayed, A. K. (2019). Time-based differences in the effects of positive and negative affectivity on perceived supervisor support and organizational commitment among newcomers. Journal of Organizational Behavior, 40, 264-281. https://doi.org/10.1002/job.2324. 
Walker, D. D., Van Jaarsveld, D. D., \& Skarlicki, D. P. (2014). Exploring the effects of individual customer incivility encounters on employee incivility: The moderating roles of entity (in)civility and negative affectivity. Journal of Applied Psychology, 99, 151-161. https://doi.org/10.1037/a0034350.

Wanous, J. P., Poland, T. D., Premack, S. L., \& Davis, K. S. (1992). The effects of met expectations on newcomer attitudes and behaviors: A review and meta-analysis. Journal of Applied Psychology, 77, 288-297. https://doi.org/10.1037/0021-9010.77.3. 288.

Watson, D., Clark, L. A., \& Tellegen, A. (1988). Development and validation of brief measures of positive and negative affect: The PANAS scales. Journal of Personality and Social Psychology, 54, 1063-1070. https://doi.org/10.1037/0022-3514.54.6. 1063.

Weiner, B. (1986). An attributional theory of motivation and emotion. New York, NY: Springer-Verlag.

Weiss, A., Michels, C., Burgmer, P., Mussweiler, T., Ockenfels, A., \& Hofmann, W. (2020). Trust in everyday life. Journal of Personality and Social Psychology. Advance online publication. https://doi.org/10.1037/pspi0000334.

Welander, J., Blomberg, H., \& Isaksson, K. (2020). Exceeded expectations: Building stable psychological contracts among newly recruited social workers in a Swedish context. Nordic Social Work Research, 10, 66-79. https://doi.org/10.1080/ 2156857X.2018.1548372.

Woodrow, C., \& Guest, D. E. (2020). Pathways through organizational socialization: A longitudinal qualitative study based on the psychological contract. Journal of Occupational and Organizational Psychology, 93, 110-133. https://doi.org/10.1111/ joop. 12285.

Zapata, C. P., Olsen, J. E., \& Martins, L. L. (2013). Social exchange from the supervisor's perspective: Employee trustworthiness as a predictor of interpersonal and informational justice. Organizational Behavior and Human Decision Processes, 121 , 1-12. https://doi.org/10.1016/j.obhdp.2012.11.001.

Zhao, H., Wayne, S. J., Glibkowski, B. C., \& Bravo, J. (2007). The impact of psychological contract breach on work-related outcomes: A meta-analysis. Personnel Psychology, 60, 647-680. https://doi.org/10.1111/j.1744-6570.2007.00087.x.

Zou, W., Tian, Q., \& Liu, J. (2015). The role of work group context and information seeking in newcomer socialization: An interactionist perspective. Journal of Management \& Organization, 21, 159-175. https://doi.org/10.1017/jmo.2014.73.

Émilie Lapointe is an Associate Professor in the Department of Leadership and Organizational Behavior, BI Norwegian Business School. Her current research is in the areas of organizational socialization, employee-supervisor relationships, employee-organization relationships, and international organizational behavior and human resource management. She has published academic articles in journals such as Human Relations, Journal of Vocational Behavior, Journal of Occupational and Organizational Psychology, Asia Pacific Journal of Management, and International Journal of Human Resource Management, and international conference papers.

Christian Vandenberghe is a Professor of Organizational Behavior at HEC Montreal and holder of the Research Chair in the management of employee commitment and performance. His research interests include organizational commitment, turnover and performance, and attitude change. His work has been published in a variety of journals, including Journal of Applied Psychology, Journal of Management, Journal of Organizational Behavior, Human Relations, Entrepreneurship Theory and Practice, Human Resource Management, Journal of Occupational and Organizational Psychology, Journal of Vocational Behavior, and Group \& Organization Management.

Cite this article: Lapointe É, Vandenberghe C (2021). Psychological contract breach and voluntary turnover among newcomers: the role of supervisor trustworthiness and negative affectivity. Journal of Management \& Organization 1-21. https:// doi.org/10.1017/jmo.2020.43 